\title{
Isolation and Identification of Probiotic Bacterial Strain from Dry Fish (Channa Punctatus)
}

\author{
Dr. Devina T G ${ }^{* 1}$, Nath, J. K. ${ }^{* 2}$, Bora $P^{3}$, Goswami $S^{4}$, Dutta $M^{5}$ \\ ${ }^{I}$ Co-ordinator/PI of Institutional Biotech Hub, D.K.D College, Dergaon, Assam, India \\ ${ }^{2}$ Retd.Co-ordinator/PI of Institutional Biotech Hub, D.K.D College, Dergaon, Assam, India \\ ${ }^{3,4,5}$ Research Fellow Institutional Biotech Hub, D.K.D College, Dergaon, Assam, India
}

*Corresponding Author: Dr. Devina T G, coordinator/PI of Institutional Biotech Hub, D.K.D College, Dergaon, Assam, India

\begin{abstract}
The dried fishes Channa punctatus were collected from the villages of Mishing community of Golaghat District and different parts of the fish was dipped in Nutrient Agar media to culture and examine the presence of probiotic bacterial strains. Gram staining and Biochemical analysis was conducted on the isolated probiotic bacterial strains. A novel probiotic bacterial strain was confirmed by NCBI after 16S rRNA sequencing.
\end{abstract}

Keywords: Isolation, Identification, $16 S$ rRNA sequencing, Probiotic, Fermented Dry Fish, Channa punctatus.

\section{INTRODUCTION}

Fish belongs to paraphyletic group of organisms which consists of all gill-bearing aquatic vertebrate animals [8]. These are ectothermic animals and are considered as tremendous sources of animal protein. Many studies reveal that fish provides a good source of high quality protein and many vitamins and minerals for maintenance of human health. It can be also used by way of drying. This has been practiced since time in memorial. Sun drying of fishes is a simple and traditional method of fish preservation. [2] Channa punctatus (snake head fish) are found abundantly in ponds and lakes of N.E, India. There number increases during June to August month when they are caught and dried in sun for preservation. Through this traditional method of drying it is found that the protein and mineral content is not lost.

The term "Probiotic" means for life since been employed to describe health promoting bacteria. The World Health Organization has defined probiotic bacteria as "live microorganism which when administrated in adequate amounts confer a health benefit on host"[12].The probiotic also defined as "a live microbial adjunct which has a beneficial effect on the host by modifying the host associated or ambient microbial community by ensuring improved use of the feed or enhancing its nutritional value, by enhancing the host response towards disease, or by improving the quality of its ambient environment". Most of the studies reveal that the bacterial species isolated from the gastrointestinal tracts of the fishes have been reported as an aerobes or facultative anaerobes. [9]

Lactic acid bacteria are considered as a Probiotics as they have probiotic properties, which can produce some inhibitory compounds such as lactic acid, hydrogen peroxide, diacetyl, bacteriocin etc. These compounds inhibit the growth of other harmful microorganisms. These are also considered as normal flora in gastrointestinal tract of aquaculture animals and mammals [11].The acid and bile tolerance and antibiotic sensitivity are the fundamental properties of probiotics [9]. The present study aimed to isolate and to identify by sequencing $16 \mathrm{~s} r$ RNA along with biochemical test.

\section{Materials ANd Methods}

\subsection{Collection and Isolation of Bacterial Strains}

The dry fish samples were collected from Mishing Gaon, Dergaon, Golaghat district of Assam, India who practiced to dry varieties of fishes use as food due to their wide acceptance among the consumers of Assam. Immediately after collection, the samples were stored aseptically in low temperature $\left(-4^{\circ} \mathrm{C}\right)$ refrigerator to protect from contamination and deterioration. The fishes were washed with sterile 
distilled water and the digestive tracts were removed from the fish in a sterile condition. The digestive tracts were homogenized in the sterile distilled water. Using serial dilution, $1 \mathrm{ml}$ of homogenized dry fish samples was inoculated on MRS broth and Nutrient broth separately followed by $24 \mathrm{hrs}$ incubation at $37^{\circ} \mathrm{C}$.After incubation, $0.1 \mathrm{ml}$ of MRS broth and Nutrient broth cultures were poured in the MRS agar and Nutrient agar plates respectively. The bacterial colonies were picked from each plate and sub cultured many times in Nutrient agar plate to get the pure culture in single colonies. The pure single colonies were identified and characterized following Bergey's Mannual of systematic Bacteriology (Whitman etal, 2009) for their colony and cell morphology, gram staining, Biochemical tests and physiological tests [3].

\subsection{Biochemical Test to Determine Probiotic Characteristics}

\subsection{1. pH Tolerance}

Acid tolerance of the selected bacterium was investigated at different $\mathrm{pH}$. First, MRS broths with different $\mathrm{pH}$ including 2, 3, 4, 5, 6, 7 and 8 were prepared using $\mathrm{HCl} 1 \%$ (Himedia) and $\mathrm{NaOH} 1 \mathrm{~N}$ (Himedia) and divided in universal bottles [10]. The broths media along with control bottles were autoclaved at $121^{\circ} \mathrm{C}$ for $15 \mathrm{~min}$ and then inoculated with overnight culture of the selected strain in MRS broth and Nutrient broth followed by incubation at $37^{\circ} \mathrm{C} \mathrm{[6].}$

\subsubsection{Bile Salt Tolerance}

Bile salt tolerance was further tested in MRS broth and Nutrient broth which included 0.0, 0.15 and $0.3 \%$ (w/v) Oxgall bile salt (Himedia). Duplicate bottles of MRS broth and Nutrient broth containing filtered different concentrations of bile salt were inoculated by $30 \mu \mathrm{l}$ of cultured strain and incubated at $37^{\circ} \mathrm{C}[5,6]$.

\subsubsection{Antibiotic Sensitivity Test}

Antibiotic sensitivity test was carried out for selected strain on the most common antibiotics in aquaculture by disc diffusion technique (Akinjogunla et al., 2010). They included Gentamycin (GM,

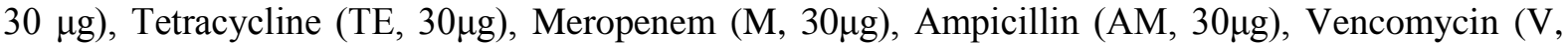
$30 \mu \mathrm{g}) .50 \mu \mathrm{l}$ of the $24 \mathrm{~h}$ broth culture of the strains were spread on MRS agar, Nutrient agar and, antibiotic Bio-discs were subsequently placed on plates. Finally, the plates were incubated at $37^{\circ} \mathrm{C}$ for 24 to $48 \mathrm{~h}$ to observe and measure the inhibition zone $[5,6]$.

\section{OBSERVATION AND RESULT}

After 24 hours of incubation, cream colored and off white colored colonies were observed in the nutrient agar and MRS agar plated respectively. The bacterial strains were identified as a strain-I (IBHDKD1) and strain-II (IBH DKD2) by NCBI after 16s r RNA sequencing. Accession No. KX683316.1 and KX668647.1.

Table1. Biochemical test results of Strain-I (Bacteria)

\begin{tabular}{|l|l|}
\hline \multicolumn{1}{|c|}{ Biochemical Tests } & \multicolumn{1}{c|}{ Results } \\
\hline Gram staining & Positive, Cocci \\
\hline Catalase & Positive \\
\hline Indole & Positive \\
\hline Citrate & Positive \\
\hline MR-VP & Negative \\
\hline
\end{tabular}

Table2. Biochemical test results of Strain-II (Bacteria)

\begin{tabular}{|l|l|}
\hline \multicolumn{1}{|c|}{ Biochemical Tests } & \multicolumn{1}{c|}{ Results } \\
\hline Gram staining & Positive, Short rod \\
\hline Catalase & Positive \\
\hline Indole & Positive \\
\hline Citrate & Negative \\
\hline MR-VP & Positive \\
\hline
\end{tabular}

Table3. PH Tolerance of Bacterial strains

\begin{tabular}{|l|l|l|l|l|l|l|c|}
\hline Strains & \multicolumn{1}{|c|}{ PH-3 } & \multicolumn{1}{c|}{ PH-4 } & \multicolumn{1}{c|}{ PH-5 } & PH-6 & \multicolumn{1}{c|}{ PH-7 } & \multicolumn{1}{c|}{ PH-8 } & PH-9 \\
\hline I & No growth & survive & survive & Grow & Grow & Grow & Grow \\
\hline II & No growth & survive & survive & Grow & Grow & Grow & Grow \\
\hline
\end{tabular}


Table4. Bile Tolerance of Bacterial strains

\begin{tabular}{|c|l|l|}
\hline Strains & \multicolumn{1}{|c|}{$\mathbf{0 . 1 5} \%$ concentration } & \multicolumn{1}{c|}{$\mathbf{0 . 3 \%}$ concentration } \\
\hline I & Survive & Survive \\
\hline II & Survive & Survive \\
\hline
\end{tabular}

Table5. Antibiotics susceptibility of Bacterial strains

\begin{tabular}{|l|l|l|}
\hline \multicolumn{1}{|c|}{ Antibiotics } & \multicolumn{1}{c|}{ StrainI } & \multicolumn{1}{c|}{ StrainII } \\
\hline Tetracyclin & Susceptible & Susceptible \\
\hline Gentamycin & Susceptible & Susceptible \\
\hline Ampicillin & Resistant & Resistant \\
\hline Meropenem & Susceptible & Susceptible \\
\hline Vancomycin & Susceptible & Susceptible \\
\hline
\end{tabular}

\section{DISCUSSION}

In the experiments, biochemical tests conducted to determine the probiotic activity of the bacteria indicates that the bacteria I show gram staining, catalase, indole and citrate reactions as positive. Only MRVP reactions are negative. The morphological shape of sample I is cocci. Table $3 \mathrm{pH}$ tolerance test indicates the minimum tolerance of the bacteria at high acidic medium and tolerance is increased as the $\mathrm{pH}$ rises.

A similar bile tolerance (table 4) is observed in the case of both the bacteria when used in different concentration. From table 5 the result of the antibiotic susceptibility test of the bacterial strain indicates both the strains are sensitive to ampicillin and susceptible to other antibiotics.

On the other hand from the table 2 it has been found the bacterial strain II is rod shaped and it shows negative result in citrate test. $\mathrm{pH}$ tolerance, bile tolerance and antibiotic susceptibility tests results are similar to that of bacterial strain I.

Phylogenetic analysis (by 16s rRNA sequencing) of the bacterial strains indicates that the bacterial strains are of Bacillus sp. and the Strains are (IBHDKD1 and IBH DKD2).

\section{CONCLUSION}

Methodical isolation forms and colony formation, biochemical test, $\mathrm{pH}$ tolerance test, Bile tolerance test results and 16s rRNA sequencing results indicates that both the bacterial strains are probiotic bacteria and they are identified as "IBHDKD1 \& IBH DKD2". It may mentioned here that further investigation is required on molecular level by determining the characters of fatty acids present in bacteria and bioassay of both the bacterial strain which may serve the need of human biological requirements.

\section{ACKNOWLEDGEMENT}

The authors are thankful to the Department of Biotechnology, govt. of India, Institutional Biotech Hub and Principal of D.K.D College Dergaon for providing necessary research facilities and technical support.

\section{REFERENCES}

[1] Akinjogunla O.J., Inyang C.U., Akinjogunla V.F.,Bacterial species associated with anatomical parts of fresh and smoked Bonga Fish (Ethmalosa fimbriata): Prevalence and Susceptibility to Cephalosporins. J. Microbiol, 6: 87-97((2010).

[2] Logesh A.R.,Pravinkumar M.,Raffi S.M.,Kalaiselvam M.,An Investigation on Microbial Screening on Salt Dried Marine Fishes.Journel of food resource science,1:(1)(15-21),ISSN2224-3550(2012).

[3] Bairagi, A., Ghosh, K.S., Sen, S.K., Ray, A.K. 2002. Enzyme producing bacterial flora isolated from fish digestive tracts. Aquacul. Int., 10: 109-121.

[4] Balcázar JL., Vendrell D., de Blas I., Ruiz-Zarzuela I., Muzquiz JL., Girones O., Characterization of probiotic properties of lactic acid bacteria isolated from intestinal microbiota of fish. Aquaculture, 278(14): 188-191(2008).

[5] Cebeci A, Gurakan C., Properties of potensial probiotic Lactobacillus plantarum strains. Food Microbiol. 20(20): 511-518. Gatesoupe FJ (1999). The use of probiotics in aquaculture. Aquaculture, 180(1-2): 147165(2003). 
[6] Kim DH, Austin B., Characterization of probiotic carnobacteria isolated from rainbow trout (Oncorhynchus mykiss) intestine. Lett. Appl. Microbiol. 47(3): 141-147(2008).

[7] Moshood A.Y. Tengku Hamid H. A. T. A...2012. Isolation and identification of Bacteria in Retailed Smoked Fish, within Bauchi Metropolis. IOSR Journal of Pharmacy and Biological Sciences (IOSRJPBS), Volume 3, PP 01-05, ISSN: 2278-3008.

[8] Oyebamiji F. ,Oyebimpe F. 2013. Microbial identification of smoke-dried fish (Clarias gariepinus) from some local markets in Ibadan metropolis. Wudpecker Journal of Agricultural Research, Vol. 2(11), pp. 294 - 298, ISSN 2315-725.

[9] P.Muthukumar, C. Kandeepan. 2015 Isolation, Identification and Characterization of Probiotic Organisms from Intestine of Fresh Water Fishes. International Journal of Current Microbiology and Applied Sciences, Volume 4 Number 3, pp. 607-616, ISSN: 2319-7706.

[10] Samelis J, Maurogenakis F, Metaxopoulos J (1994). Characterisation of lactic acid bacteria isolated from naturally fermented Greek dry salami. Int. J. Food Microbiol. 23: 179-196.

[11] Sayyed Allameh K., Md. Yusoff F., Daud H. M., Ideris A. 2012. Isolation, identification and characterization of Leuconostoc mesenteroides as a new probiotic from intestine of snakehead fish (Channa striatus). African Journal of Biotechnology Vol. 11(16), pp. 3810-3816 ISSN 1684-5315.

[12] Vijayaram1 S., Kannan1 S. and Muthukumar S., Isolation and characterization of probiotic bacteria isolated from diverse fish fauna of the trodden Vaigai River at Theni district. Journal of Chemical and Pharmaceutical Research 8(7):883-889, ISSN: 0975-7384(2 016).

Citation: T. G. Devina et al., "Isolation and Identification of Probiotic Bacterial Strain from Dry Fish (Channa Punctatus)", ARC Journal of Pharmaceutical Sciences (AJPS) , vol. 3, no. 3, p. 1-4, 2017. http://dx.doi.org/10.20431/2455-1538.0303001

Copyright: () 2017 Authors. This is an open-access article distributed under the terms of the Creative Commons Attribution License, which permits unrestricted use, distribution, and reproduction in any medium, provided the original author and source are credited. 